\title{
ISLAM AND THE TWENTY-FIRST CENTURY
}

\author{
16-20 Muharram 1417/3-7 June 1996 \\ Department of Southeast Asia \& Oceania \\ Leiden University, Leiden, The Netherlands
}

On 4 June 1996, a plenary session was held at Groot Auditorium, in the Academy Building of Leiden University. This session was chaired by Professor Leertouwer, the vice-chancellor and rector of Leiden University (est. 1575), who also gave the opening address. In his speech, he emphasized the importance of the conference theme and referred to one of the most noteworthy and influential Dutch scholars, Snouck Hurgronje, who taught at the university between 1907 and 1921 and contributed to the field of Islamic studies in a unique manner. $\mathrm{He}$ then introduced Tarmizi Taher, Indonesia's current minister of religious affairs, who delivered the opening address along with Abdelkabir Alaoui M'daghri, Morocco's current minister of waqf and Islamic affairs, and a representative of the Netherland's Ministry of Education, Culture, and Science. The minister of the Netherlands was not able to attend the conference.

The Indonesian minister, a trained medical doctor, used his opening address to stress the importance of research in Islamic studies and to concentrate upon Dutch-Indonesian cooperation in this field. The Moroccan minister's speech was well received; the minister was added to the program at the last minute when it was learned that he would be visiting the country at that time. Tht title of his speech was "Coexistence in the New World Order." A lawyer by training, he raised the issue of human rights and prefaced it by commenting upon the changes that have taken place over the centuries and the manner in which societies and communities took control of their circumstances.

The keynote speaker, Riffat Hassan (University of Louisville, KY, USA) gave a speech titled "What Does it Mean to be a Muslim on the Eve of the Twenty-First Century?" A social anthropologist by training, she addressed the topic and drew quite a bit upon her own life history as a woman. The audience generally found her feminist ideas to be very provocative and challenging.

It was indeed unfortunate that one of the first parallel sessions was cancelled because one of the key participants fell ill. The other panelists for this session were fitted into other sessions. Ataullah Bogdan Kopan- 
ski (International Islamic University, Malaysia) delivered his provocative and lengthy conference paper entitled "Islam under Siege: The Reception of the Threat from the West and the Concept of Tyranny in Contemporary Muslim European Thought." An interesting debate ensued. Vernon February (University of the Western Cape, South Africa, and Leiden University), who presented an interesting paper, "The Cape Muslim Community and Social Justice in South Africa," shared the platform with Muhammed Haron (University of the Western Cape, South Africa), who presented his paper "Reshaping Old Identities and Adopting New Ones in a New South Africa: The Case of the South African Muslims" and Abdou Filali-Ansary, the famous Moroccan social anthropologist, who discussed "Achievements and Prospects of the Islamic Reformation."

The first session, which seemed to attract a great deal of interest, was the one in which Nasr Abu Zayd, a visiting professor from Egypt, presented his paper "Islam and Modernity." Before he joined Leiden University as a visiting professor, he had been criticized severely by the traditionalists for his views on the interpretation of the Qur'an. His paper did not, however, generate much debate, even though it was speculated that it would because of the controversy surrounding his ideas on, and his interpretation of, the Qur'an. He tried to forward a theoretical model that modernity started when Islam appeared, and was criticized by some of the participants. His co-panelist, Lukas Werth, a German anthropologist, presented an interesting and well-articulated paper "Pakistan: A Critique of the Concept of Modernity."

Three parallel sessions were held, each focusing upon a different theme. In the session on globalization, Naimah Talib (Institute of Southeast Asian Studies and editor of Sojourn: Journal of Social Issues in Southeast Asia) assessed critically "Sources of Regime Legitimacy: The Sultanate of Brunei as an Independent State." Imtiyaz Yusuf (Faculty of Islamic Studies, Prince Songkla University, Thailand) outlined "Islam and Democracy in Thailand: The Case of the 1993 Islamic Administrative Bill." He was followed by Abdel-Aziz Shady (Department of Political Science, Cairo University), whose paper "The Role of Ifta in Egypt's Foreign Policy, 1977-1992." was well received by the audience and generated an interesting discussion.

During the following morning, three parallel sessions addressed globalization, development, and education. The one on globalization analyzed relations between Southeast Asia and the Middle East. Azyumardi Azra (editor of Studia Islamica, an Indonesian journal of Islamic studies, and member of IAIN), spoke on "Globalization of Muslim Discourse: Contemporary Religio-Intellectual Connections between Indonesia and the Middle East." Nico Kaptein (Leiden University) addressed "Fatwas as a Unifying Factor in Indonesian History." Mona Abaza (The American University of Cairo and ISS, Singapore), 
focused on "Some Patterns of South-South Cultural Perceptions: An Indonesian Azhari in Cairo."

A third set of parallel sessions was held in the afternoon. Kopansky was slotted into this session along with Michael Mastura, a Philippine member of Parliament, and Muhammad Hisyam, an Indonesian scholar (Leiden University) involved in the INIS project. Hishyam presented "The Dynamics of Religion and State Relations in Indonesia: The Case of the Islamic Court," and Mastura presented "The Relocation of Legitimacy in an Interdependent Community: The Islamic Context in South-East Asia." While Hisyam's paper was well received (it was based on his doctoral dissertation field work), Mastura's came across as highly problematic and speculative. Kopansky presented a very contentious paper and was taken to task for some of his assumptions.

In the fourth set of parallel sessions that afternoon, the themes covered the media, development and gender, and globalization. The session on the media had two panelists: Jeroen Peeters (The International Institute of Southeast Asian Studies, Leiden) and Malik Fadjar (Ministry of Religious Affairs, Indonesia). The former presented the paper "Islamic Publishers in Indonesia: An Analysis of Social Networks," and the latter presented "Islam in Printed Publications in Indonesia."

Two very interesting papers were presented on the penultimate day of the conference. Southeast Asian specialist Howard Federspiel (McGill University, Canada) presented "South-East Asian Muslim Intellectuals: The Sources of Their Arguments in the Middle East, the West, and South-East Asia Itself." Mohammad Atho Mudzhar (Ministry of Religious Affairs, Indonesia) looked at "The Ulama', the Government, and Society in Modern Indonesia," which examined the relationship between Muslim clerics, the government, and the society and reflected the sensitive and complex nature of their relationship.

Later that morning, Japanese Southeast Asian scholar Mitsou Nakamura (Chiba University, Japan) analyzed the "Perspectives of Indonesian Muslim Intellectuals into the Twenty-First Century: ICMI Five Years Later." He shared the session with Zohurul Bari Azmi (Jawaharlal Nehru University, India), whose presentation was "NeoSalafiya: (Is It) A Universal Ideology of Political Islam?” From the subsequent discussion, it appears that Nakamura's scholarship on Indonesia is generally well respected.

On the last day of the conference, the first three sets of parallel sessions were held. Two panelists, Belgacem Alioui (Ministry of Religious Affairs, Tunisia) and Abdelkader Semmari, a North African scholar, presented their papers in Arabic. Although the latter's "Dialogue and Cooperation between Muslims and Europeans" in some way complemented the former's paper "Islam, the Religion of Tolerance, Moderation, and Development," Alioui's paper did not 
contribute anything new or exciting to the existing debates on these specific themes.

In the last set of sessions, Nico Landman (Utrecht University, the Netherlands) presented an interesting paper, "Training Imams in the Netherlands: Motivations, Opportunities, Barriers." He was joined by Jaafar Majed (Tunis University, Tunisia), who addressed "The Education of Individuals and Groups in Islam," and Ali Kettani (rector, Ibn Rushd University, Spain), who spoke on "Toward Indigenous Islamic Education Facilities in Western Europe and the Potential Impact on the Muslim World." Kettani, who has spent years teaching in many parts of the Middle East, made a very interesting contribution by looking at the past and present regarding Islamic education. He spent some time addressing his experiment in Spain.

On the whole, the conference was a very exciting one that managed to gather together a fair number of Southeast Asian scholars of Islamic Studies - perhaps for the first time on European soil-and made it possible for them to interact with scholars of other academic institutions. The conference was jointly hosted by the Department of Southeast Asia and Oceania, the Department of Religious Studies, Department of Languages and Cultures of the Islamic Middle East, and the Royal Institute of Linguistics and Anthropology at Leiden University.

Muhammed Haron Department of Arabic Studies University of the Western Cape Bellville, South Africa 